\title{
SLC9A9 Gene
}

National Cancer Institute

\section{Source}

National Cancer Institute. SLC9A9 Gene. NCI Thesaurus. Code C125267.

This gene is involved in intracellular organelle ion homeostasis. 